\title{
Durability Experiences on the Traditional and SCM Founded Blended Concrete
}

\author{
Eti Tirumala Chakrapani, A M N Kashyap, G Anjaneyulu, M R Manikanta
}

\begin{abstract}
Concrete might be the maximum substantially used construction material in the global with approximately six billion tones being produced each year. It is best subsequent to water in phrases of in keeping with-capita consumption. However, environmental sustainability is at stake both in terms of damage due to the extraction of raw material and $\mathrm{CO} 2$ emission all through cement manufacture. This brought pressures on researchers for the discount of cement intake by means of partial substitute of cement by using supplementary materials. These materials may be obviously happening, industrial wastes or by way of-products that are less energy extensive. Fly ash and Ground Granulated Burnt Slag (GGBS) are selected specifically based totally on the standards of fee and their long lasting qualities., Not best this, Environmental pollution also can be decreased to a point due to the fact the emission of dangerous gases like carbon monoxide \& carbon dioxide are very restricted. These substances (referred to as pozzalonas) when combined with calcium hydroxide, reveals cementitious compositions. Most commonly used pozzalonas are fly ash, silica fume, met kaolin, ground granulated blast furnace slag (GGBS). This wishes to look at the admixtures performance whilst combined with concrete so as to ensure a discounted existence cycle fee. The present research consists of three phases and reports the specializes in investigating characteristics of M35grade concrete. In the 1st phase the behavior of standard and SCM concrete (7.5\%FA and 7.5\%GGBS) of M35 grade specimens with different percentages of chemical admixtures curing with acids such as HCL. 2nd phase the same grade of specimens curing with Alkaline such as $\mathrm{NaOH}$ and in the 3rd phase the same grade of specimens curing with sulphate solution $\mathrm{MgSO} 4$ and finally assess the losses of mechanical properties and durability considerations of the concrete due to these conditions were reported.
\end{abstract}

Key words: Durability, sustainability, chemical admixture, grade of concrete, ground granular based blast furnace slag, fly ash, curing

\section{INTRODUCTION}

Now-a-days the most suitable and broadly used construction material is concrete. This constructing material, till in recent times, went through lots of tendencies. The definition of concrete is the mixture of cement, water, additives or every so often outstanding-plasticizers. It is artificial material. In the beginning it is soft, ductile or fluid,

Manuscript received on March 31, 2021.

Revised Manuscript received on April 03, 2021.

Manuscript published on October 10, 2021.

* Correspondence Author

Eti tirumala Chakrapani*, Civil Engineering Department, Giet Engineering College, Rajahmundry, India. Email: parimalaeti@yahoo.com

A M N Kashyap, Civil Engineering Department, Giet Engineering College, Rajahmundry, India.

G Anjaneyulu, Civil Engineering Department, Giet Engineering College, Rajahmundry, India.

M R Manikanta, Civil Engineering Department, Giet College of Engineering College, Rajahmundry, India.

(c) The Authors. Published by by Lattice Science Publication (LSP). This is an open access article under the CC BY-NC-ND license (http://creativecommons.org/licenses/by-nc-nd/4.0/) and steadily will be stable. We can don't forget this Constructing material as an artificial stone. The major part of concrete is cement. The manufacturing process of this raw material produces a variety of $\mathrm{CO} 2$. It is well known, that $\mathrm{CO} 2$ emission initiates dangerous environmental modifications. Nowadays researchers make efforts to minimize emission of $\mathrm{CO} 2$ due to fast improvement in Industrial sector in the world. The simplest way to minimize the $\mathrm{CO} 2$ emission of cement industry is to substitute a share of cement with different materials. These materials known as supplementary cementing materials (SCM's). Usually used supplementary cementing substances are Ground Granulated Blast Furnace Slag (GGBS), Fly Ash (FA), Silica Fume (SF), Trass or Met kaolin (MK).These are generally industrial byproducts, subsequently the introduction of SCM's by partial replacement of cement consequences less $\mathrm{CO} 2$ at some point of cement manufacturing. The SCM's offer different blessings and that is why the utilization inside the concrete generation is increasingly more trendy. The purpose of our inspection is to get familiar with those SCM's and to examine a few features. The maximum exciting feature is to boom cheical resistance of concrete.

We will awareness in our examinations on GGBS and FA. In our experiments we inspect an effect on of SCM's on weight reduction and on the strength additionally. In this research at we describe the results of examinations and conclusions with GGBS \& FA. We gift the experimental program the in addition activities and works.

Durability is the other parameter in considering the life of concrete. The Portland cement concrete resists from the weathering motion, chemical assault, abrasion, or another procedure of decay is defined as the durability. No matter in the world is constitutionally durable, on this basis when concrete interacts with the environment interactions the microstructure and the material characteristics alter with time. Where the material is reached to its least service life and it shows poor in performance and strength characteristics, concluded that the live of that material is reached its unsafe conditions.

Magnesium, potassium, calcium and sodium are the most important minerals anywhere in the earth soils and they may be in the soil or ground water. Among all the sulphate minerals the liquefaction of CaSo 4 is less, so that ground waters having high percentage of other sulphates and less of calcium sulphate, and the important observation are that the magnesium suphate cause more damage to the concrete than others. The waste water from industrial usage and form cultivation land ammonium sulphate is highly presence. In wet and muddy lands the production of hydraulic sulphate is more progressive and this often converts in to sulphuric acid due to bacterial action.

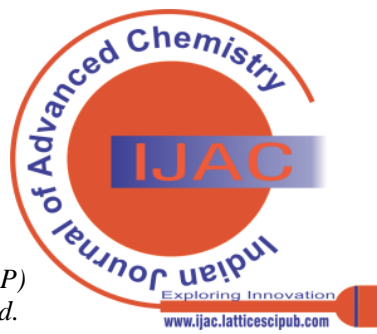


On this basis the sulphate attack through the water is most common issue in the common and industrial operations. Sulphates soluble in the water they made big damage by penetrate in to the small pores in concrete and reacts with the hydrated cement contents. A Characteristic silver appearance is the identification of sulphate attack. The time period sulphate assault denote an influence in the quantity of cement paste in concrete or mortar because of the chemical motion among the products of hydration of cement and solution containing sulphates. In the sulphuric attack the volume of concrete is rises to $200 \%$ due to slow dissolution of concrete.

\section{LITERATURE ON SUBJECT}

Qian and Caijun [1] the untapped cementitious properties of slags was reveled from his paper and that alkali based slags like iron ore slag, phosphorus slag, blast furnace slag are the recent supplementary cementitious materials in the construction area. C.A.Clear [2] as per his research paper the early age strength of the concrete is gets slow down, its depends on the percentage of replacement of cement with GGBS, Ganesh Babu, K., and Sree Rama Kumar, V. [3] the influence of the GGBS as a partial replacement of cement in concrete in strength characteristics was listed in this paper. Mahesh Patel, Prof. P. S. Rao and T. N. Patel[4] in this paper ,the compressive strength of concrete with and without mineral admixture like GGBS was studied and reported that strength characters were enhanced in the concrete with mineral admixtures added to the concrete. A Cheng, Ran Huang et al. [5] studied on the sustainability of GGBS concretes and RCC beams corrosion nature under different combinations of load conditions. Vaishak K, Susan Abraham [6] reported that strength characteristics were increase for Fly ash and GGBS concrete compared with target mix. Neethu Susan Mathew, S. Usha [7] states this research that the durability of geopolymer concrete was enhanced due to the pore size in the concrete is minimizes by particle size of the admixture. Finally The aim of this paper is to reveal the characteristics of the GGBS and Fly ash based concrete at different levels of replacement and their mechanical and durability properties.

\section{RESULTS AND DISCUSSION}

In this research work, the mix designation of M35 was carried out according to IS:10262 (2009) recommendations. The $150 \mathrm{~mm}$ cube specimens of various concrete mixtures with mineral and chemical admixtures were cast to test compressive strength. The cube specimens after de-moulding were stored in curing tanks and on removal of cubes from water the compressive strength were conducted at 7 days and 56 days.

\subsection{WORKABILITY TESTS FOR FRESH CONCRETE}
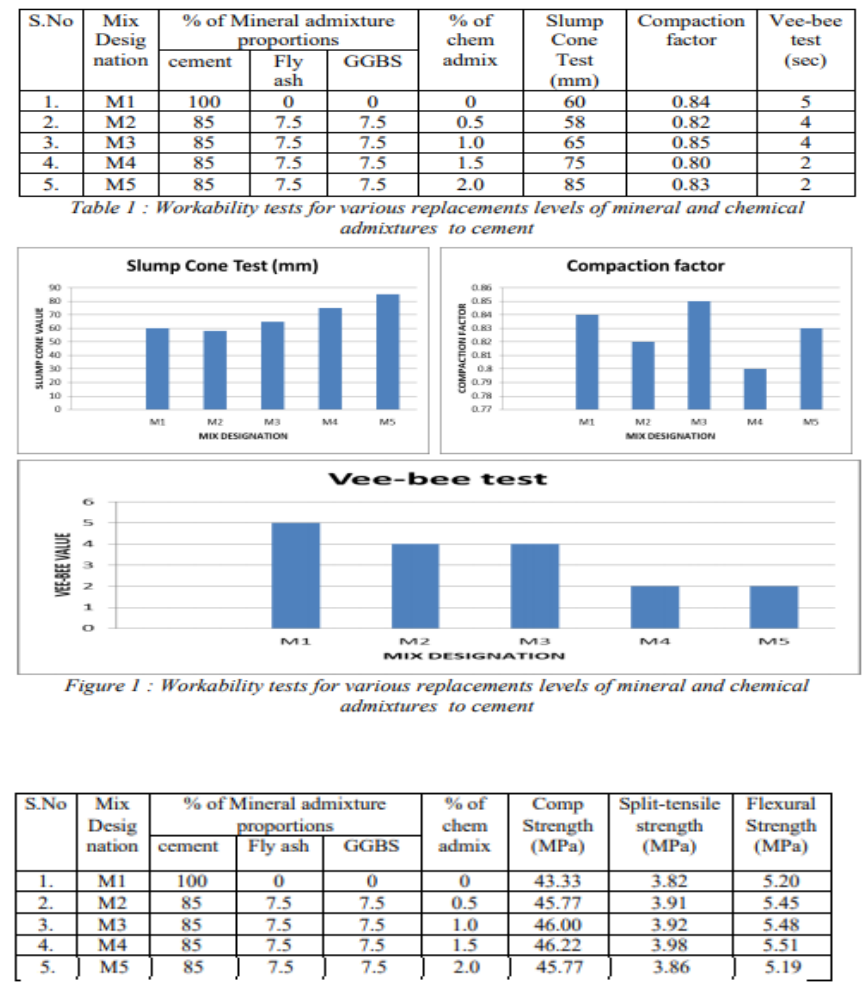
|Table 2: Test results of M35 grade concrete with various replacements of chemical
admixtures

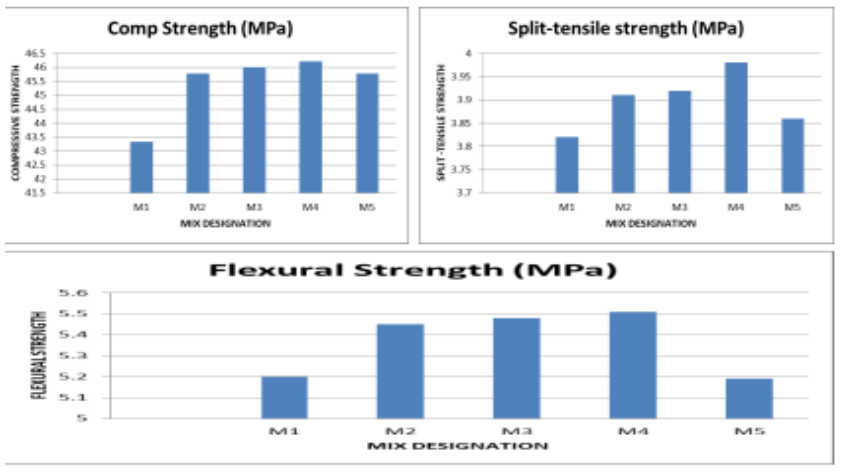

Figure 2: Test results of M35 grade concrete with various replacements of chemical admixtures

\section{2. $1^{\mathrm{ST}}$ PHASE TEST RESULTS}

The concrete specimens of various concrete mixtures with chemical(HI-FORZA 245) and mineral admixtures(7.5\%Fly ash and $7.5 \%$ GGBS ) of size $150 \mathrm{~mm}$ were cast and leave for 24 hours of dry curing, the specimens were removed from the mould and allowed to dry for another one day.

These specimens were dipped in to the $5 \%$ of HCL contained water tank for 7 days and 56 days and removed those samples after the specified test period and testing for mechanical properties and reported.

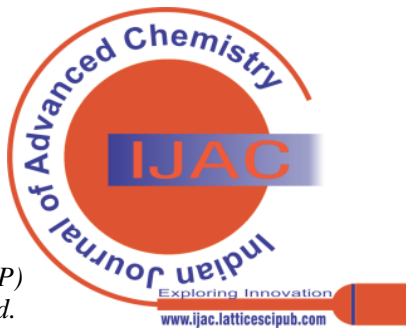




\begin{tabular}{|c|c|c|c|c|c|c|c|c|}
\hline \multirow[t]{2}{*}{ S.No } & \multirow{2}{*}{$\begin{array}{c}\text { Mix } \\
\text { Desig } \\
\text { nation }\end{array}$} & \multicolumn{3}{|c|}{$\begin{array}{l}\% \text { of Mineral admixture } \\
\text { proportions }\end{array}$} & \multirow{2}{*}{$\begin{array}{l}\% \text { of } \\
\text { chem } \\
\text { admix }\end{array}$} & \multirow{2}{*}{$\begin{array}{l}\text { Comp } \\
\text { Strength } \\
(\mathrm{MPa})\end{array}$} & \multirow{2}{*}{$\begin{array}{c}\text { Split- } \\
\text { tensile } \\
\text { strength } \\
(\mathrm{MPa})\end{array}$} & \multirow{2}{*}{$\begin{array}{l}\text { Flexural } \\
\text { Strength } \\
(\mathrm{MPa})\end{array}$} \\
\hline & & cement & Fly ash & GGBS & & & & \\
\hline 1. & M6 & 100 & 0 & 0 & 0 & 43.31 & 3.69 & 5.15 \\
\hline 2. & M7 & 85 & 7.5 & 7.5 & 0.5 & 45.81 & 3.92 & 5.39 \\
\hline 3. & M8 & 85 & 7.5 & 7.5 & 1.0 & 46.06 & 3.97 & 5.49 \\
\hline 4. & M9 & 85 & 7.5 & 7.5 & 1.5 & 46.27 & 3.97 & 5.58 \\
\hline 5. & M10 & 85 & 7.5 & 7.5 & 2.0 & 45.79 & 3.88 & 5.17 \\
\hline
\end{tabular}

Table 3: Test results of M35 grade concrete after 7 days deep water bath with $5 \% \mathrm{HCL}$
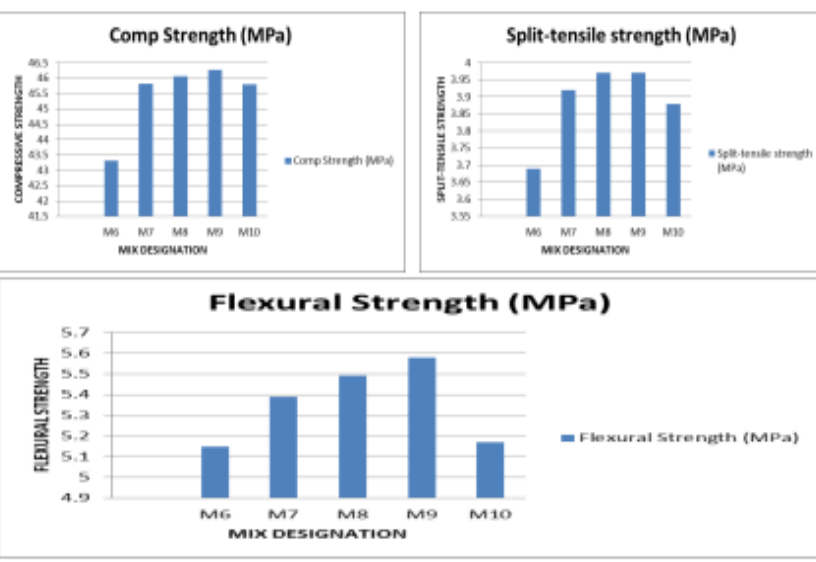

Figure3: Test results of M35 grade concrete after 7days deep water bath with $5 \% \mathrm{HCL}$

\begin{tabular}{|c|c|c|c|c|c|c|c|c|}
\hline S.No & $\begin{array}{c}\text { Mix } \\
\text { Desig } \\
\text { nation }\end{array}$ & \multicolumn{2}{|c|}{$\begin{array}{c}\text { \% of Mineral admixture } \\
\text { proportions }\end{array}$} & \multirow{2}{*}{$\begin{array}{c}\text { \% of } \\
\text { chem } \\
\text { sdmix }\end{array}$} & $\begin{array}{c}\text { Comp } \\
\text { Strength } \\
(\mathrm{MPa})\end{array}$ & $\begin{array}{c}\text { Split- } \\
\text { tensile } \\
\text { strength } \\
(\mathrm{MPa})\end{array}$ & $\begin{array}{c}\text { Flexural } \\
\text { Strength } \\
(\mathrm{MPa})\end{array}$ \\
\hline 1. & M11 & 100 & 0 & 0 & 0 & 43.25 & 3.64 & 5.12 \\
\hline 2. & $\mathrm{M} 12$ & 85 & 7.5 & 7.5 & 0.5 & 45.74 & 3.84 & 5.39 \\
\hline 3. & $\mathrm{M} 13$ & 85 & 7.5 & 7.5 & 1.0 & 46.04 & 3.95 & 5.49 \\
\hline 4. & $\mathrm{M} 14$ & 85 & 7.5 & 7.5 & 1.5 & 46.18 & 4.02 & 5.58 \\
\hline 5. & $\mathrm{M} 15$ & 85 & 7.5 & 7.5 & 2.0 & 45.77 & 3.86 & 5.17 \\
\hline
\end{tabular}

Table 4: Test results of MB5 grade concrete after 56dqus deep water bath with $5 \%$ HCL
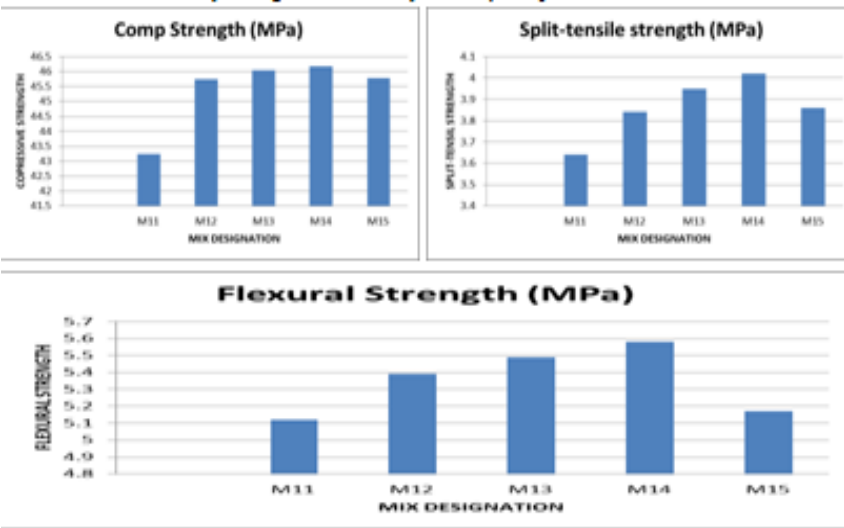

Figure 4: Test results of MBS grade concrete after 50dqus deep water bath with $5 \%$ HCL

\section{3. $2^{\text {ND }}$ PHASE TEST RESULTS}

The concrete specimens of various concrete mixtures with chemical(HI-FORZA 245) and mineral admixtures(7.5\%Fly ash and 7.5\% GGBS ) of size $150 \mathrm{~mm}$ were cast and leave for 24 hours of dry curing, the specimens were removed from the mould and allowed to dry for another one day. These specimens were dipped in to the $10 \%$ of $\mathrm{NAOH}$ contained alkaline water tank for 7 days and 56 days and removed those samples after the specified test period and testing for mechanical properties and reported.

\begin{tabular}{|c|c|c|c|c|c|c|c|c|}
\hline S.No & $\begin{array}{c}\text { Mix } \\
\text { Desig }\end{array}$ & \multicolumn{2}{|c|}{$\begin{array}{c}\text { \% of Mineral admixture } \\
\text { proportions }\end{array}$} & \multirow{\%}{*}{$\begin{array}{c}\text { \% of chem } \\
\text { admix }\end{array}$} & $\begin{array}{c}\text { Comp } \\
\text { Strength } \\
\text { nation }\end{array}$ & $\begin{array}{c}\text { Split-tensile } \\
\text { strength } \\
\text { (MPa) }\end{array}$ & $\begin{array}{c}\text { Flexural } \\
\text { (MPa) }\end{array}$ & $\begin{array}{c}\text { Strength } \\
\text { (MPa) }\end{array}$ \\
\hline 1. & M16 & 100 & 0 & 0 & 0 & 43.21 & 3.68 & 5.14 \\
\hline 2. & M17 & 85 & 7.5 & 7.5 & 0.5 & 45.76 & 3.90 & 5.44 \\
\hline 3. & M18 & 85 & 7.5 & 7.5 & 1.0 & 45.97 & 3.95 & 5.49 \\
\hline 4. & M19 & 85 & 7.5 & 7.5 & 1.5 & 46.20 & 3.98 & 5.52 \\
\hline 5. & M20 & 85 & 7.5 & 7.5 & 2.0 & 45.80 & 3.87 & 5.19 \\
\hline
\end{tabular}

Table 5: Test results of M35 grade concrete affer 7days deep water bath with $10 \% \mathrm{NAOH}$
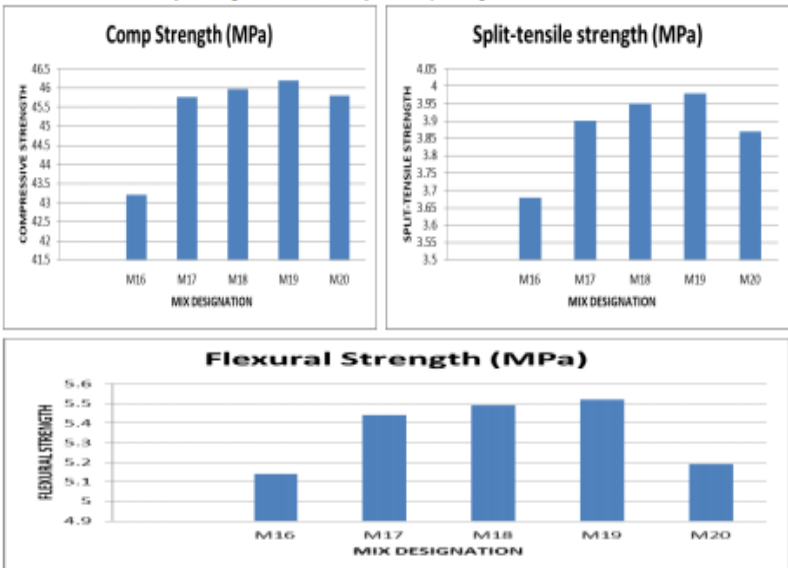

Figure 5: Test results of $M 35$ grade concrete after 7 davs deep water bath with $10 \% \mathrm{NAOH}$

\begin{tabular}{|c|c|c|c|c|c|c|c|c|}
\hline S.N0 & $\begin{array}{c}\text { Mix } \\
\text { Desig } \\
\text { nation }\end{array}$ & \multicolumn{3}{|c|}{$\begin{array}{c}\text { \% of Mineral admixture } \\
\text { proportions }\end{array}$} & $\begin{array}{c}\text { \% of } \\
\text { chem } \\
\text { admix }\end{array}$ & $\begin{array}{c}\text { Comp } \\
\text { Strength } \\
(\mathrm{MPa})\end{array}$ & $\begin{array}{c}\text { Split- } \\
\text { tensile } \\
\text { strength } \\
(\mathrm{MPa})\end{array}$ & $\begin{array}{c}\text { Flexural } \\
\text { Strength } \\
(\mathrm{MPa})\end{array}$ \\
\hline 1. & M21 & 100 & 0 & 0 & 0 & 42.98 & 3.62 & 5.02 \\
\hline 2. & M22 & 85 & 7.5 & 7.5 & 0.5 & 45.71 & 3.82 & 5.33 \\
\hline 3. & M23 & 85 & 7.5 & 7.5 & 1.0 & 45.91 & 3.92 & 5.41 \\
\hline 4. & M24 & 85 & 7.5 & 7.5 & 1.5 & 46.14 & 3.86 & 5.48 \\
\hline 5. & M25 & 85 & 7.5 & 7.5 & 2.0 & 45.71 & 3.82 & 5.12 \\
\hline
\end{tabular}

Table 6: Test results of M35 grade concrete after 56days deep water bath with $10 \% \mathrm{NAOH}$
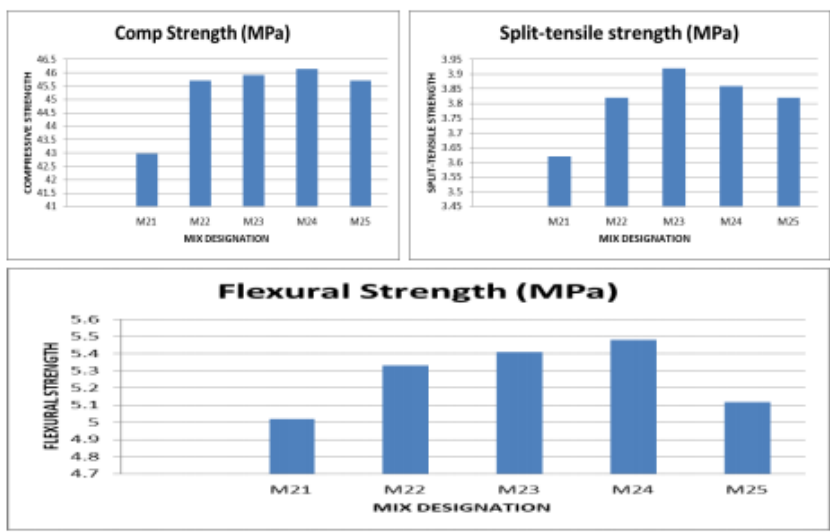

Figure 6: Test results of M35 grade concrete after 56days deep water bath with $10 \% \mathrm{NAOH}$

\subsection{RD PHASE TEST RESULTS}

The concrete cube specimens of various concrete mixtures with chemical(HI-FORZA 245) and mineral admixtures(7.5\%Fly ash and 7.5\% GGBS ) of size $150 \mathrm{~mm}$ were cast and leave for 24 hours of dry curing, the specimens were removed from the mould and allowed to dry for another one day. These specimens were dipped in to the 5\%Mg2SO4 contained sulphate water tank for 7 days and 56 days and removed those samples after the specified test period and testing for mechanical properties and reported.

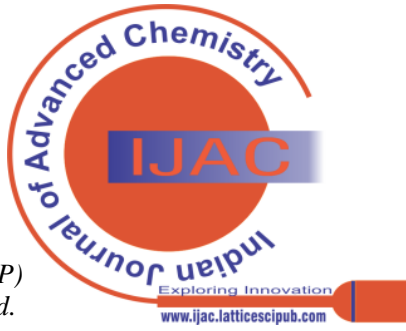



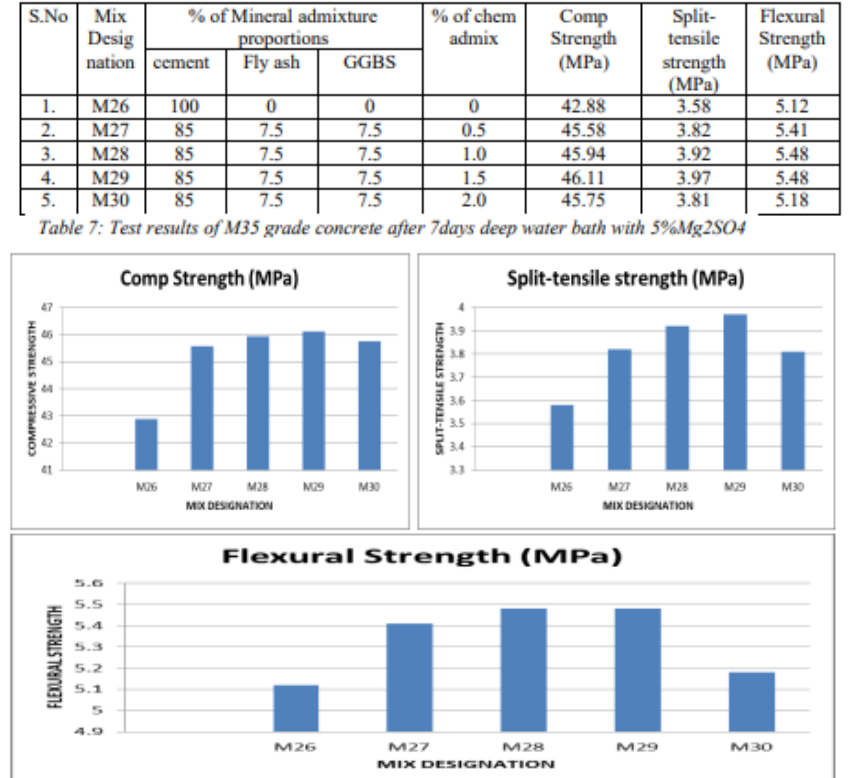

Figure 7: Test results of M35 grade concrete affer 7 days deep water bath with $5 \% \mathrm{Mg} 2 \mathrm{SO} 4$

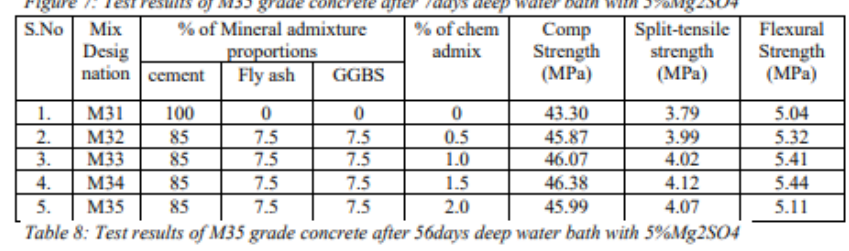

Table 8: Test results of $\mathrm{M} 35$ grade concrete after 56 days deep water bath with $5 \% \mathrm{Mg} 2 \mathrm{SO}$

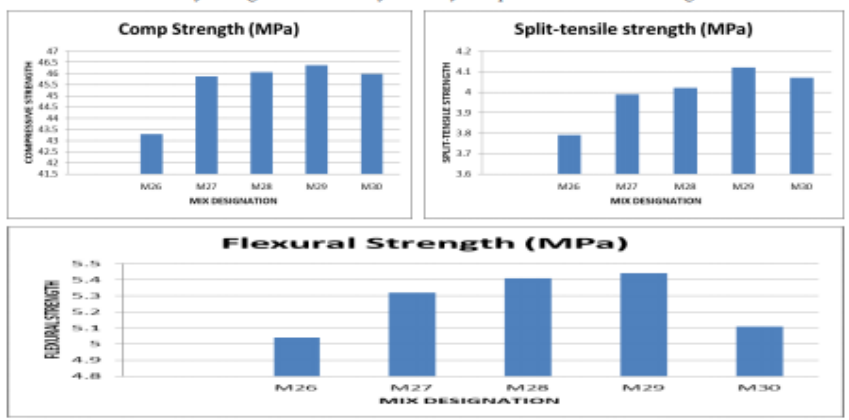

Table 8: Test results of $\mathrm{M} 35$ grade concrete after 56days deep water bath with 5\%Mg2SO4

\section{CONCLUSIONS}

1. GGBS and Fly ash in to the concrete with the chemical admixture enhances the Workability

2. The compressive strength of concrete increases at the 1.5 $\%$ chemical admixture to the concrete

3. The split tensile strength of concrete also increases at the $1.5 \%$ chemical admixture is to the concrete

4. The physical and mechanical properties of the concrete more affected at $0.5 \%, 1 \%$ and $2 \%$ ratios of chemical admixture to the concrete when affected to the acid attack

5. The concrete at all ratios of chemical admixtures are highly influenced towards the disintegration of structure and mechanical properties

\section{REFERENCES}

1. Qian Jueshi and Shi Caijun, - High performance cementing materials from industrial slags - a evaluation Resources, Conservation and Recycling 29, 1 June 2000, 195-207

2. C. A. Clear, -Formwork striking time for Ground Granulated Blast furnace Slag concrete: test and site result\| Building Board Structural and Structural Panel Paper 10517 Nov.441-448 Bldgs. 1995, 104,

3. Ganesh Babu, K., and Sree Rama Kumar, V. - Efficiency of GGBS in concrete. Cem. Concr. Res., 2000, 1031- 1036.

4. Mahesh Patel, Prof. P. S. Rao and T. N. Patel "Experimental Investigation on Strength of High Performance Concrete with GGBS and Crusher Sand" PARIPEX - INDIAN JOURNAL OF RESEARCH, Volume: 3 | Issue: 4 | May 2013 ISSN - 2250-1991
5. An Cheng, Ran Huang - Influence of GGBS on durability and corrosion behavior of reinforced concrete Materials Chemistry and Physics93, Issues 2-3, 15 October 2005, pages 404-41

6. Vaishak K, Susan Abraham" Study on Strength and Durability Properties of GGBS-Fly Ash based Concrete" IOSR Journal of Engineering (IOSRJEN) www.iosrjen.org ISSN (e): 2250-3021, ISSN (p): 2278-8719 Vol. 08, Issue 6 (June. 2018), ||V (II) || PP 69-76.

7. Neethu Susan Mathew, S. Usha "Study on strength and durability of fly ash and ggbfs based geopolymer concrete" International Research Journal of Engineering and Technology (IRJET) e-ISSN: 2395-0056 Volume: 02 Issue: 05 | Aug-2015 www.irjet.net p-ISSN: 2395-0072

8. IS: 383-1970: Specifications for Coarse and Fine Aggregates for Natural Sources of Concrete, Bureau of Indian Standards, New Delhi.

9. IS: 10262-2009: Concrete Mix Proportioning-Guidelines, Bureau of Indian Standards, New Delhi. [10]. IS: 516-1959: Methods of Tests for Strength of Concrete, Bureau of Indian standards, New Delhi.

10. IS: 12269-1987, Specification for 53 Grade Ordinary Portland Cement, Bureau of Indian Standards, New Delhi, India, 1989.

\section{AUTHORS PROFILE}

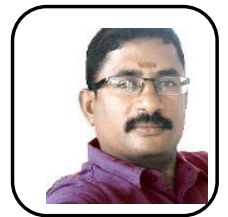

E T Chakrapani, is currently working as a Head of the department \& Asst Professor in department of civil engineering, GIET Engineering College, Rajamahendravaram, A.P and pursuing his Ph.D in GITAM University. He obtained his Master of Technology from Jawaharlal Nehru Technological University, Kakinada, Andhra Pradesh. He has severa publications in National and International Journals. His areas of interest are in Special Concretes and Design of Concrete Structures.

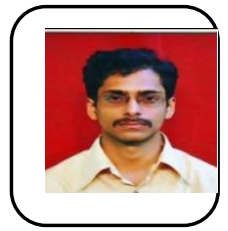

A M N Kashyap, is currently working as a Asst Professor in department of civil engineering, GIET Engineering College, Rajamahendravaram,A.P and pursuing his Ph.D in JNTU H . He obtained his Master of Engineering with gold medal from Andhra University, Andhra Pradesh. He has severa publications in National and International Journals. His areas of interest are in alternative materials in concrete, soil stability exposures and and Design of water retaining Concrete Structures.

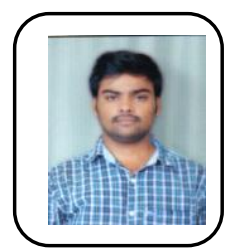

Gadde Anjaneyulu, is currently working as a Asst Professor in department of civil engineering, GIET Engineering College, Rajamahendravaram,A.P and he obtainedhis Master of Technology from Jawaharlal Nehru Technological University, Kakinada, Andhra Pradesh. He has several publications in National and International Journals. Concrete Repairing Materials. His areas of interest are in Remote sensing \& GIS,

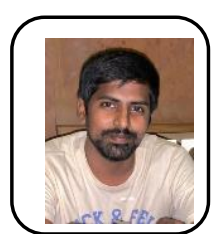

Maddula Rama Manikantha, is currently working as a Head of the department \& Asst Professor in department of civil engineering, GIET College of Engineering, Rajamahendravaram, A.P and he obtainedhis Master of Technology from Jawaharlal Nehru Technological University, Kakinada, Andhra Pradesh. He has several publications in National and International Journals. His areas of interest are in concrete materials and design of high rise structures 